\title{
Legal Life: Conceptual, Categorical and Methodological Analysis Experience
}

\author{
Alexander V. Mal'ko*a and Vasily V. Trofimov ${ }^{\mathrm{b}}$ \\ ${ }^{a}$ Saratov Branch \\ of the Institute of State and Law of RAS \\ 135 Chernyshevsky Str., Saratov, 410028, Russia \\ ${ }^{b}$ Tambov State University named after G.R. Derzhavin \\ 33 International Str., Tambov, 392000, Russia
}

Received 14.02.2015, received in revised form 09.04.2015, accepted 21.05.2015

The present article describes the experience of conceptual, categorical, and methodological analysis of the legal life phenomenon. It assesses the critical sides and advantages, reflecting the process of introducing the "legal life" category into legal theory structure. It substantiates the theoretical and methodological potential of the "legal life" category and considers the problem of development of separate methodological approaches to legal life development.

Keywords: legal life of the society, legal theory, categories of legal science, scientific discussion, law, complexity phenomenon, methodology, synergetic approach, cultural-historical approach.

DOI: 10.17516/1997-1370-2015-8-8-1652-1660.

Research area: law.

Complex processes and challenges typical for the development of contemporary society require adequate scientific efforts for the registration and analysis of the forming patterns and tendencies. In this regard, one of the tasks of scientific search is the creation of the categories that would reflect such processes and challenges to the full, being able to explain the new appearing social realities, suggest solutions for the new economic, political, moral and other problems. Legal science is not an exception, suffering from significant deficit in the field of the most general concepts, justified from the methodological point of view (assuming a certain philosophical, scientific conceptuality), that could be used for comprehensive research of the complex, contradictory and multifaceted processes observed in the legal development of various countries.

Among such concepts going through the process of formation at the turn of the $21^{\text {st }}$ century, we may outline the category of legal life ${ }^{1}$, which can be interpreted as a form of social life, manifesting itself predominantly in legal acts and legal relations characterizing the specificity and level of legal development of the given society, the relation of subjects to law and the degree of their interests' satisfaction ${ }^{2}$.

(c) Siberian Federal University. All rights reserved

* Corresponding author E-mail address: igp@sgap.ru 
This is the category serving to reflect the complexly developing and contradictory legal reality, the inextricable connection of the diverse legal phenomena with all other spheres of social life, e.g. economic, political, moral, religious etc.

Within the context of modern conceptual and categorical apparatus of legal studies, the legal life category is intended to compensate the well-known lack of methodologically relevant categories, reflecting the whole spectrum of legal phenomena. It gains special prospects considering the features of post-classical stage of scientific rationality, which introduces new criteria for the understanding and interpretation of being. Along with that, having entered the field of legal theory, the category began to go through these or those "waves" of critical remarks. The main reason for it was its exposure to traditional (classical) scientific thinking measures, which blocked the methodological potential specific, for the legal life category, leading thereby to certain problems in the process of its identification within the system of theoretic-legal concepts and categories ${ }^{3}$.

The question became a debating point from the very beginning ${ }^{4}$. Moreover, the fact of attention to the problem itself means that it required deeper consideration ${ }^{5}$. At least, there are the following aspects that need to be settled. First of all, it is necessary to determine the advantages of introducing the legal life category into the structure of conceptual and categorical apparatus of law theory; secondly, to reveal the methodological prospects of applying this categorical matrix to legal problem analysis; thirdly, to justify the fact that legal life can serve as an object of legal science that does not only suggest rich material for research, but also brings practically all legal methodology to the state of "readiness", as "methods" only make sense in the presence of an appropriate "object" of search.

Characterizing the first of the mentioned aspects, we should also remark that separation of legal science with regard to the use of so-called "life strategy" of cognition of the legal phenomena world from other fields of humanitarian knowledge looks unreasonable. In political and economic science the terms of political life, economic life etc. have already acquired the appropriate categorical status ${ }^{6}$. This complex and multi-aspect concepts are used to reflect some complex phenomena of politics and economics. Moreover, we can suggest that the arrival of the mentioned fields of research to the necessity to use these concepts was neither artificial nor strained; it is quite evident to be the result of certain objective processes of development of scientific knowledge, and tendencies of moving on to the next levels (types) of rationality?

And if it is so, why does not legal science accept these simple facts and does not step on these lines (tendencies) of scientific knowledge development? The heuristic advantages of such innovations are evident. They bring a new categorical matrix, which is the concept of legal life, without blurring the object of legal knowledge, but bringing it not only to a technical (legaldogmatic), but also a truly social (sociallegal) character, which is exactly what legal science is intended to be in its purpose. And in this case, "if "organization of the legal life of the society (Italics by A.M., V.T.)' is considered as the base for the subject of general legal theory..., then the conceptual conclusions and postulates of general legal theory shall be the theories of functioning legal requirements not only within the legal 
system, but also within the system of social life of society" " The so-called "pure" jurisprudence does not even attempt to see these simple truths, though it is obliged to accept them sooner or later, when "life" forces it to.

The discussion around the scientific status of legal life of society arose because this concept began to claim for what until recent time the term of "legal system" claimed for: for becoming an ultimately wide category encompassing all legal phenomena. In this regard, N.I. Matuzov remarks that "recently some legal experts began to introduce, besides the established category of "legal system", common both in our country and abroad (being an extremely wide, collective and multi-element concept), a parallel concept, which would be more capacious to their minds: that is the concept of legal life".

However, it is evident that the mentioned categories should not be considered as parallel or equal. It appears that inclusion into legal system of non-systematic phenomena that can have a feature of "legal" would hardly be efficient, as, though being directly related to law, they may contradict it: those are, for instance, legal vacuum, legal chaos, legal alienation etc., i.e. all the phenomena that fallout from the systematic bonds, destructing them but still present in the life of society itself. Would the category of "legal system" be ready to cover all these nonsystematic phenomena, even if its theoretical and methodological frameworks are forcedly widened (as, one should admit, a systematic approach does not exclude the consideration of negative phenomena and "entropy" in the system as certain manifestations of systematicity and systematic mechanisms) ${ }^{10}$ ? Would the legal system doctrine (theory) accept these aspects, which is also questionable; and if yes, does it really need it ${ }^{11}$ ?
The legal life term, including the legal system term, encompasses more than just static, but, first of all, the dynamic processes happening in the legal field and contains not only systematic, but also non-systematic segments. As it was rightfully remarked, "legal life is a process, it is the reality in its dynamics that sooner or later, but always arrives at the crystallization of legal relations or their destruction,... opposed to the legal life term, the legal system term describes society from the point of view of one structure as a product of social processes' crystallization"'2.

Unlike the legal system category, the legal life category bears a somewhat different meaning and performs a methodological task to consider legal phenomena in a wider way (and here we start the brief description of the second of the mentioned key aspects of the problem). Legal life can be considered as the general whole, which justifies and unites all other legal phenomena into an integrity (the use of the "integrity" term assumes the use of the "integrative approach" standing behind it and completing the "systematic approach") $)^{13}$.

The presence of "life" or "living world" category (phenomenological tradition) in the foundation of studying the legal phenomena world makes it possible to make an attempt of building a perceptual vision of this world based on life (legal life). With the legal life category the process of cognizing law itself will acquire an integrated character, encompassing the whole spectrum of initial and derivative, static and dynamic, normative and non-normative, positive and negative, organized and disorganized, material and spiritual legal phenomena, uniting them into a whole, demonstrating them as a "summarized totality" of legal life.

Being a complex and an ultimately generalizing category, from the view of methodology and within the legal science framework, it, to our mind, can open the potential 
of meta-systematic approach uniting various types of knowledge: firstly, the domain or actual and empirical knowledge based on the "immediate, external, single" elements of law ${ }^{14}$; secondly, the systematic knowledge that launches legal analysis to a wider orbit, assuming the consideration of law on different levels (law within the social system; legal system as a whole of social legal phenomena; objective law system $)^{15}$ and, thirdly, the complex knowledge born on the basis of multi-aspect, multi-dimensional understanding and modeling of cognition objects, let those be systematic or non-systematic ${ }^{16}$.

Legal life shall therefore be regarded as an integrated object of general legal theory, as a "legal metasystem" (i.e. more than "just a system"). Therefore, the introduction of the "legal life" term into legal science terminology and granting it a certain scientific status transforms many research parameters, allowing to consider more than just the "external part" (positive, formal, rational, controllable), but also the underlying part of legal life that often slips away from the researcher's eye (negative, informal, irrational, non-controllable). With this special theoretical-methodological construction it is possible to encompass the totality of all the forms of social and legal organization of society, along with the internal feature of law or legal features ${ }^{17}$.

The methodological technique contained in it is used to unite the formal and essential sides of law, to demonstrate the processes of emergence, development and extinction of legal forms in parallel with legal life itself "as the source of morphogenesis" (Simmel G.). It provides an opportunity to see not only the effect of monoorientation of law to the achievement of the result established in the regulation (the legal goal), but also the process of the legal form's reaction to the continuously transforming social medium conditions. It is in the development of legal forms that "we learn the parallel of life and law. In any sense of the word, law is nothing but collective will; in this regard, just like natural law, it is a form or simply a spirit of the relations the matter of which is group living, or, in more universal words, the intertwining of will spheres ... " ${ }^{18}$.

To our mind, it is legal life that, as a phenomenon of social reality, self-sufficient due to its separateness from any subjective factors and self-developing due to some internal reasons transforming positive law into an efficient tool of legal influence, establishes the necessary communication bonds between the social subjects themselves, as well as between the social subjects and legal regulations. Encompassing the objective pre-requisites of complex subject-object-subject type of interaction, legal life makes up a dialogue between natural law and law as an element of noosphere, which, interpenetrating into each other, make up the conditions of social life's existence on the basis of law.

Doubtlessly, such vision of the legal research object requires activation of methodological resources (third aspect of the problem), which in itself is a positive factor for law and legal science as a whole. With such understanding of what is to be studied (with the understanding of the whole legal diversity and depth of legal phenomena), the legal-technical tool set (including the logical, linguistic tools etc.) is not enough. As the object of research is not only (and not as much as) legal texts and forms of their formulation, but the whole environment of legal life, therefore the methodology has to be based on all the levels (from the philosophical as the highest and to the empirical as the lowest, from the general scientific to specifically legal). One should also notice that together with the traditional (classical) one, including dialectic, systematic etc., a significant role can be played by the new (post-classical) approaches and methods (synergetic, integrative, communicative etc.). 
For instance, it seems promising to use the potential provided by the synergetic approach which is used for the research of the "complexity" phenomenon, typical of legal life as of no other legal phenomenon. As K.V. Shundikov rightfully remarks in his work dedicated to justification of the potential of synergetic approach in legal science, it is required to concentrate the initial attention on the phenomenon of complexity of the studied object (law) and form the scientific approach correspondingly to interpret and to explain this feature of law. Only in this case one can expect the formation of the optimal patterns of formalization and regulation of the development process of the legal sphere of social life $\mathrm{e}^{19}$.

The author makes another important remark that what the synergetic approach is able to change is not as much of the traditional idea of the formal and structural features of law (the internal aspect of the problem), but the "vision of the perceptual picture of its functioning and interaction with other factors of social medium, causing the present conditions of social and legal order in the totality of their influence" ${ }^{20}$. Therefore, we emphasize the aspect, external in its relation to positive law, which is a rule positioned within the sociological type of law cognition, with the synergy acting as a pre-requisite for the renewal and deepening of understanding of the social essence of law and the tendencies of legal life as a whole.

One of the theses presented by the opponents of introducing the legal life category into the theory of law is its incompliance with the understanding of law as a certain field of something "right", positively legal. Thus, E.N. Chernykh notices that the "desire to encompass all known world of law and a specific form of social life in one category brings to the confusion of cognitive strategies and tools, and, consequently, to incoordination of constructs and elements. Even the name of the category, "legal life" which is the synthesis of the Things in Existence being "life" and of the Right being "legal", reveals the eclecticity of its construction as a problem of uniting two ontologically different and usually opposed spheres: the actual reality and the sphere of ideals, regulations and values, which is the result of combination of such different cognitive strategies as sociological and statutory-axiological" ${ }^{21}$.

It is really eclectic, but it is the eclectics determined by life itself. Otherwise, what (what object) would the sought "right" be applied to, if not to the "thing in existence", and how can the independence of both be achieved? It seems that the Kant's theses of theoretical thinking criticism including the denial (impossibility of finding) the standards of "right" in the "things in existence"22, would hardly serve as a significant argument both in the issues of considering legal life to be a category of sociological-legal order (and, in this sense, a component of the terminological apparatus of general theory of law), and of law as a standard-axiological status which, nevertheless, does not lose its social character and has to be, therefore, regarded only in its connection with social life. The strictly dogmatic approach (with elements of subjective-idealistic philosophy) applied by the critics of "legal life" in this case, deprives us of the opportunity to see that, separated from life, law is just an empty "form", closed for living contents.

Entering an imaginary discussion with the followers of such one-way (simplified) view over the legal reality which may be composed of only positive, rightful, legitimate phenomena, K.V. Shundikov convincingly argues that such interpretation of the system of legal regulation "means unawareness of its complex nature and 
intentional simplification of the epistemological and methodological tasks of legal science, as there is a series of problems (problem of law formation and law functioning, in particular) that is impossible to set or study without going beyond the 'strictly legal' field"23.

We cannot but agree with such opinion. As remarked by S.S. Alexeev, who had done a lot for the establishment and development of the so-called objective concept of law: "Law and all parts of legal regulation mechanism exist objectively, presenting thereby real phenomena of social life" 24 .

Law is social reality, which is the only way for law to find its way to life: "the system of law is not real as such for being embodied in material forms, but it is real as, regulating the activities of individuals, it gets thereby included into the real process of life, becoming an element of the existing objective social relations" ${ }^{25}$.

The same synergetic approach can be used for deep and sufficient consideration of various dynamic (positive and negative) processes of legal life (stability and instability, cooperation and competition of the legal order parameters; progress and regress, cycles of legal development, consistent and occasional elements of legal life). It denies neither modernization of the "legal order concept" as a systematic component of legal life, nor the creation of a foundation for a new concept of legal forecasting (taking all possible crises and deviations into account) etc. It justifies the research prospects (quite material and demanded) that assist the further development of legal science and appear due to the application of the described synergetic approach ${ }^{26}$.

No doubt, the legal life research requires involvement of many other methods and approaches. No matter how paradoxical it may sound, but under the conditions of globalization the cultural and historical aspects of our country's legal life require thorough studies, thereby calling for mew methodological tools. The task of modern methodology in our country is to find such dimension of law that would not break the integrity of this legal phenomenon with the spiritual order of Russia and its unique cultural world. For this reason V.N. Siniukov and T.V. Siniukova emphasize that "the legal life category introduced by A.V. Mal'ko is quite likely to fulfill the role of methodological concept of law even in the event of specific legal constructivization of the known legal objects. This theoretical task is extremely complicated" ${ }^{27}$. And here legal life would act both as an object of applying the appropriate methods (culturological, cultural and historical) and a methodological tool able to express the existing national, mental, cultural peculiarities of legal life of certain nations.

It is rightfully remarked that "the concept of 'legal life of society' reflects the inseparable bond of legal phenomena with all other spheres of society"28, that introduction of legal life as a category "reflects the development tendencies of Russian legal thought, leading it to major expansion of the legal reality boundaries", that "legal thought has reached the point (stage, step etc.) when it requires to include the general cultural factors into the researcher's view" 29 .

It is rightfully stated that "by today we have reached the stage when we need to treat the existing facts of Russian legal life from some new, uncommon positions: not from the formally legal, sociological, psychological, cybernetic or abstractlyhuman ones, but through the prism of the national-historical and cultural-typological nature of Russian legal world for the sake of 
studying its wholeness and systematicity as it is. There is no coincidence that it happened in the post-reformation period, when Russian legal science began to develop the category of legal life as an attempt to look at Russian legal phenomena from some new social-cultural and dogmatic positions. The category of legal life, to great extent, marks the achievement of a different, synergetic and comparative-legal aspect of studying national legal phenomena" ${ }^{30}$.

Therefore, legal life begins to take a well-proven position in the structure of legal theory. Its appearance in the scientific context brings a number of advantages. First of all, it concerns the development of terminological-categorical apparatus of legal theory: being an ultimately wide category, legal life of society enables the researchers to establish (clarify) the boundaries of other categories related to it in any way ("legal system", "legal reality" etc.); to express the relations between these interconnected categories and see what such connections are manifested in; secondly, it expands the horizons of studying legal problems, transforms the research parameters enabling us to consider the details that used to fall out from the scientifically legal context; and, finally, this strategy of legal phenomena cognition opens up the resources of legal methodology, making it more demanded and efficient. All together, these advantages boost the further development of modern legal science, solving the functional tasks accompanying the scientific cognition of law.

\footnotetext{
One should also notice that the use of this category took place back in Soviet legal science. Thus, S.S. Alexeev in his works pointed at the possibility of using the legal life category. He saw it as a generalizing synthetic concept encompassing legal phenomena in both static and dynamic aspects, i.e. the whole world of legal phenomena. - For example, see Alexeev S.S. Obshchaia teoriia prava [General Theory Of Law]. Vol.1. Moscow, 1981. P. 91.

2 For more details see: Mal'ko A.V. Novye iavleniia v politiko-pravovoy zhizni Rossii: voprosy teorii i praktiki [New Phenomena In Political And Legal Life Of Russia: Theory And Practice Issues]. Tolyatti, 1999; Ibid. Politicheskaia i pravovaia zhizn' Rossii: aktual'nye problemy [Political And Legal Life Of Russia: Issues Of The Day]. Moscow, 2000. P. 35; Ibid. "Pravovaia zhizn"” kak vazhneyshaia kategoriia iurisprudentsii ["Legal Life" As The Essential Category Of Legal Studies] // Zhurnal Rossiyskogo prava. 2000. No.2; Ibid. Sovremennaia rossiyskaia pravovaia politika i pravovaia zhizn' [Modern Russian Legal Policy And Legal Life] // Pravovaia politika i pravovaia zhizn'. 2000. November. P. 21; Ibid. Kategoriia “pravovaia zhizn"”: problemy stanovleniia [Legal Life Category: Problems Of Establishment] // Gosudarstvo i pravo. 2001. No.5; Ibid. Pravovaia zhizn': osnovy teorii [Legal Life: Theoretical Basis] // Pravovaia zhizn' v sovremennoy Rossii: teoretiko-metodologicheskiy aspekt / Edited by N.I. Matuzov and A.V. Mal'ko. Saratov, 2005. P. 43; Ibid. Teoriia pravovoy politiki [Legal Policy Theory]: monograph. Moscow, 2012. P. 34 etc.

3 The prerequisites of changes in the worldview basis (towards the new types of rationality) began becoming relevant as necessary and "mature" in Soviet philosophy in the late 80-s. - For example, see: Lektorskiy V.A. Sovremennoe nauchnoe poznanie i razvitie teoretiko-poznavatel'nykh issledovaniy (\$ 1) [Contemporary Scientific Cognition And Development Of Theoretical And Cognitive Research (§ 1)] // Dialektika, poznanie, nauka / Edited by V.A. Lektorskiy, V.S. Tiukhtin. Moscow, 1988. P. 5-13.

4 For example, see: Baranov V.M. Tenevoe pravo [Shadow Law]. Nizhniy Novgorod, 2002; Matuzov N.I. Pravovaia zhizn' kak ob'iekt nauchnogo issledovaniia [Legal Life As A Scientific Research Object] // Pravovaia zhizn'v sovremennoy Rossii: teoretiko-metodologicheskiy aspekt. P. 9-38; Bryzgalov A.I. Iuridicheskaia nauka segodnia: teoretiko-metodologicheskie problemy, kotorye zhdut resheniia [Legal Science Today: Theoretical And Methodological Problems Awaiting Solution] // Zhurnal rossiyskogo prava. 2001. No.6. P. 48; Ibid. O nekotorykh teoretiko-metodologicheskikh problemakh iuridicheskoy nauki na sovremennom etape [On Certain Theoretical And Methodological Problems Of Legal Science On The Modern Stage Of Development] // Gosudarstvo i pravo. 2004. No.4. P. 20-21; Aslanian N.P. Poniatie grazhdansko-pravovoy real'nosti: postanovka problemy [Civil And Legal Reality Concept: Problem Setting] // Obshchestvo, politika, ekonomika, pravo. 2010. No.1. P. 69-76; Aslanian N.P. Poniatie pravovoy real'nosti: postanovka tsivilisticheskoy problemy [Legal Reality Concept: Civil Problem Setting] // Izvestiia Irkutskoy gosudarstvennoy ekonomicheskoy akademii. 2012. No. 5. P. 100-108; Lichman B.V. Mnogokontseptual 'nost' metodologii rossiyskoy iurisprudentsii [Multiconceptuality Of Russian Law Methodology] // Newsletter of the Ural Institute of Economics, Administration and Law. 2013. No. 2. P. 60-67; Chernykh E.N. Kategoriia "pravovaia zhizn"': voprosy metodologii [“Legal Life" Category: Methodological Issues] // Pravovaia politika i pravovaia zhizn'. 2014. No.3. P. 8-15 etc.
} 
5 The problem of studying the legal life phenomenon was developed in a series of contemporary works: Trofimov V.V. Pravovaia zhizn': teoreticheskie i sotsial'no-filosofskie problemy issledovaniia [Legal Life: Theoretical And SocialPhilosophical Problems Of Research] // Pravovaia politika i pravovaia zhizn'. 2003. No. 4. P. 124-133; Mikhaylov A.E. Pravovaia zhizn' sovremennoy Rossii: problemy teorii i praktiki [Legal Life Of Modern Russia: Theory And Practice Problems]: abstract from a dissertation for the academic degree of a Candidate of Law. Saratov, 2004; Pravovaia zhizn'v sovremennoy Rossii: teoretiko-metodologicheskiy aspekt [Legal Life In Modern Russia: Theoretical And Methodological Aspect] / edited by N.I. Matuzov and A.V. Mal'ko. Saratov, 2005; Zatonskiy V.A., Mal'ko A.V. Kategoriia "pravovaia zhizn"”: opyt teoreticheskogo osmysleniia ["Legal Life" Category: Theoretical Interpretation Experience] // Pravovedenie. 2006. No. 4. P. 4-17; Mal'ko A.V., Mikhaylov A.E. Pravovaia zhizn' obshchestva [Legal Life Of The Society]. Saratov, 2007; Shiianov V.A. Pravovaia sistema i pravovaia zhizn' obshchestva: teoreticheskiy aspekt vzaimodeystviia [Legal System And Legal Life Of The Society: Theoretical Aspect Of Interaction]: abstract from a dissertation for the academic degree of a Candidate of Law. Moscow, 2008; Trofimov V.V. Kontseptsiia pravovoy zhizni: teoretiko-metodologicheskoe znachenie [Legal Life Concept: Theoretical And Methodological Significance] // Pravovaia politika i pravovaia zhizn'. 2009. No. 2. P. 61-68; Mal'ko A.V., Trofimov V.V. Teoretiko-metodologicheskoe znachenie kontseptsii "pravovoy zhizni" [Theoretical And Methodological Significance Of "Legal Life" Concept] // Gosudarstvo i pravo. 2010. No. 7. P. 5-13; Nozdrin A.N. Pravovaia zhizn' kak kategoriia sovremennoy iuridicheskoy nauki [Legal Life As A Category Of Modern Legal Science]: abstract from a dissertation for the academic degree of a Candidate of Law. Mariupol, 2013, etc..

6 For example, see: Luzan A.A. Politicheskaia zhizn' obshchestva: voprosy teorii [Political Life Of Society]: monograph. Kiev, 1989; Borisenkov A.A. Politicheskaia zhizn' obshchestva [Political Life Of Society] // Sotsial'no-politicheskie nauki. 1991. No. 7; Chudinova I.M. Politicheskaia zhizn' [Political Life] // Sotsial'no-politicheskiy zhurnal. 1994. No. 1112; Krasnov B.I. Politicheskaia zhizn' obshchestva i eio demokraticheskie parametry [Political Life Of Society And Its Democratic Parameters] // Sotsial'no-politicheskiy zhurnal. 1995. No. 4 etc.

7 See: Stepin V.S. Samorazvivaiushchiesia sistemy i postneclassicheskaia ratsional'nost' [Self-Developing Systems And Post-Non-Classical Rationality] // Voprosy filosofii. 2003. No. 8. P. 5-17.

8 Zimanov S.Z. Mesto obshchey teorii prava v sovetskom pravovedenii [Place Of General Theory Of Law In Soviet Legal Studies] // Sovetskoe gosudarstvo i pravo. 1984. No. 4. P. 16.

9 Matuzov N.I. Pravovaia zhizn' kak ob'ekt nauchnogo issledovaniia [Legal Life As A Scientific Research Object] // Pravovaia zhizn' v sovremennoy Rossii: teoretiko-metodologicheskiy aspekt. P. 11.

10 See: Popkov V.V. Dvoystvennost': kontseptsiia i struktura poznavatel'noy modeli [Duality: The Concept And The Structure Of A Cognitive Model] // Sistemnyy podkhod v sovremennoy nauke. Moscow, 2004. P. 235-236.

11 See also: Trofimov V.V. Pravovaia sistema i pravovaia zhizn' kak sposoby poznaniia iuridicheskikh iavleniy [Legal System And Legal Life As Means Of Cognition Of Legal Phenomena] // Pravovaia zhizn' v sovremennoy Rossii: teoretikometodologicheskiy aspekt. P. 123-148; Ibid. O metodologicheskom potentsiale kategoriy "pravovaia zhizn"” $i$ "pravovaia sistema" [On Methodological Potential Of Categories "Legal Life" And "Legal System" // Pravovaia politika i pravovaia zhizn'. 2006. No. 2 (23). P. 20-31..

12 Malakhov V.P., Eriashvili N.D. Pravovaia zhizn', eio soderzhanie i formy [Legal Life, Its Forms And Contents] // Metodologicheskie i mirovozzrenchskie problemy sovremennoy iuridichskoy teorii. Moscow, 2011. P. 76.

13 About it, see: Reznik Iu.M. Vvedenie v sotsial'nuiu teoriiu: Sotsial'naia sistemologiia [Introduction To Social Theory: Social Systemology]. Moscow, 2003. P. 330-331.

14 Tiunova L.B. Sistemnye sviazi pravovoy deytstvitel'nosti [System Bonds Of Legal Reality]. Saint Petersburg, 1991. P. 11.

15 See: Ibid. P. 19.

16 Reznik Iu.M. Op.cit., P. 324.

17 Zakomlistov A.F. Iuridicheskaia filosofiia [Philosophy Of Law]. Saint Petersburg, 2003. P. 45.

18 Tönnies F. Obshchnost' $i$ obshchestvo [Community And Society]. Saint Petersburg, 2002. P. 295.

19 See: Shundikov K.V. Sinergeticheskiy podkhod v pravovedenii. Problemy metodologii i opyt teoreticheskogo primeneniia [Synergetic Approach In Legal Studies. Methodology Problems And Theoretical Application Experience] Moscow, 2013. P. 37.

$20 \quad$ Ibid. P. 41

${ }_{21}$ For example, see: Chernykh E.N. Op.cit. P. 9

22 About this, see: Novgorodtsev P.I. Kant i Gegel'v ikh ucheniiakh o prave i gosudarstve [Kant and Hegel In Their Studies Of Law And State]. Saint Petersburg, 2000.

23 Shundikov K.V. Op.cit. P. 44.

24 Alexeev S.S. Obshchaia teoriia sotsialisticheskogo prava [General Theory Of Socialist Law]. Issue IV. Sverdlovsk, 1966. P. 199.

25 Galkin B.A. Pravo kak sotsial'naia real'nost' [Law As Social Reality] // Voprosy filosofii. 1978. No. 8. P. 79-80.

26 See also: Shundikov K.V. Ustoychivost' i nestabil'nost'v pravovoy zhizni obshchestva [Stability And Instability In Legal Life Of Society] // Sovremennoe pravo. 2008. No. 1. P. 33-38; Ibid. Poriadok otnosheniy v sisteme pravovoy zhizni obshchestva: sinergeticheskiy podkhod [Order Of Relations In The System Of Legal Life Of Society: Synergetic Approach] // Leningradskiy iuridicheskiy zhurnal. 2010. No. 2 (20). P. 22-36 etc..

27 Siniukov V.N., Siniukova T.V. K obnovleniiu metodologii iuridicheskoy nauki [To The Update Of Legal Science Methodology] // Sovremennye metody issledovaniia v pravovedenii / Edited by N.I. Matuzov and A.V. Mal'ko. Saratov, 2007. P. 38.

28 Bel'skiy K.T. Formirovanie i razvitie sotsialisticheskogo pravosoznaniia [Formation And Development Of Socialistic Legal Consciousness]. Moscow, 1982. P. 30.

29 Pravo i kul'tura [Law And Culture] / edited by N.S. Sokolova. Moscow, 2002. P. 66. 
30 Siniukov V.N. Rossiyskaia pravovaia sistema. Vvedenie v obshchuiu teoriiu [Russian Legal System: Introduction To General Theory]: monograph. $2^{\text {nd }}$ edition. Moscow, 2010. P. 18.

\title{
Правовая
}

\section{жизнь: опыт понятийно-категориального}

\section{и методологического анализа}

\author{
А.В. Малько ${ }^{a}$, В.В. Трофимов ${ }^{\sigma}$ \\ ${ }^{a}$ Саратовский филиал \\ Института государства и права РАН \\ Россия, 410028, Саратов, ул. Чернышевского, 135 \\ ${ }^{6}$ Тамбовский государственный университет \\ имени Г.Р. Державина \\ Россия, 392000, Тамбов, ул. Интерначиональная, 33
}

Статья посвящена характеристике опыта понятийно-категориального и методологическогоанализафеноменаправовойжизниобщества. Очениваютсякритические стороны и преимущества, отражающие процесс введения категории «правовая жизнь» в структуру теории права. Обосновывается теоретико-методологический потенциал, присущций категории «правовая жизнь», рассматривается проблема развития отдельных методологических подходов исследования правовой жизни.

Ключевые слова: правовая жизнь общества, теория права, категории юридической науки, научная дискуссия, право, феномен «сложности», методология, синергетический подход, культурно-исторический подход.

Научная специальность: 12.00.00 - юридические науки. 